\title{
Optimization and Molecular Characterization of Exoelectrogenic Isolates for Enhanced Microbial Fuel Cell Performance
}

\author{
Kingsley Ekene Nwagu ${ }^{1 *}$, Imo A. Ekpo ${ }^{2}$, Benjamin Utip Ekaluo ${ }^{2}$, Godwin Michael Ubi ${ }^{2}$, Munachimso Odinakachi Elemba ${ }^{1}$, \\ and Uzoh Chukwuma Victor ${ }^{1}$ \\ ${ }^{1}$ Department of Biology/Microbiology/Biotechnology, Faculty of Science, Alex Ekwueme Federal University Ndufu Alike Ikwo, Ebonyi State, \\ Nigeria \\ ${ }^{2}$ Department of Genetics and Biotechnolgy, Faculty of Biological Science, University of Calabar, Cross River State, Nigeria
}

Received: December 5, 2018 / Revised: March 24, 2019 / Accepted: March 28, 2019

\begin{abstract}
In this study we attempted to screen bacteria and fungi that generate electricity while treating wastewater using optimized double-chamber microbial fuel cell (MFC) system parameters. Optimization was carried out for five best exoelectrogenic isolates (two bacteria and three fungi) at $\mathrm{pH}$ values of 6.0, 7.5, 8.5, and 9.5, and temperatures of $30,35,40$, and $45^{\circ} \mathrm{C}$; the generated power densities were measured using a digital multimeter (DT9205A). The isolates were identified using molecular characterization, followed by the phylogenetic analysis of isolates with known exoelectrogenic microorganisms. The bacterium, Proteus species, N6 (KX548358.1) and fungus, Candida parapsilosis, S10 (KX548360) produced the highest power densities of 1.59 and $1.55 \mathrm{~W} / \mathrm{m}^{2}$ (at a $\mathrm{pH}$ of 8.5 and temperatures of 35 and $40^{\circ} \mathrm{C}$ ) within $24 \mathrm{~h}$, respectively. Other fungiClavispora lusitaniae, S9 (KX548359.1) at $40^{\circ} \mathrm{C}$, Clavispora lusitaniae, S14 (KX548361.1) at $35{ }^{\circ} \mathrm{C}$-and bacterium-Providencia species, $\mathrm{N} 4(\mathrm{KX} 548357.1)$ at $40{ }^{\circ} \mathrm{C}$-produced power densities of $1.51,1.46$, and $1.44 \mathrm{~W} / \mathrm{m}^{2}$, respectively within $24 \mathrm{~h}$. The MFCs achieved higher power densities at a pH of 8.5, temperature of $40^{\circ} \mathrm{C}$ within $24 \mathrm{~h}$. The bacterial isolates have a close evolutionary relationship with other known exoelectrogenic microorganisms. These findings helped us determine the optimal $\mathrm{pH}$, temperature, evolutionary relationship, and exoelectrogenic fungal species other than bacteria that enhance MFC performance.
\end{abstract}

Keywords: Exoelectrogenic isolates, optimization, pH, phylogenetic tree, power density, temperature

\section{Introduction}

Environmental pollution and energy crises are recent challenges of the ecosystem. Increased agricultural, industrial and domestic activities by humans have led to great environmental pollution and the quest for renewable energy in our society. Sustainable economic development through agricultural and industrial activities faithfully relies on renewable energy sources that are

\section{*Corresponding author}

Tel: +234-8063285094

E-mail: kingpetit.kn@gmail.com

() 2019, The Korean Society for Microbiology and Biotechnology eco-friendly, affordable and accessible [15]. Previous and some contemporary methods of controlling environmental pollution and energy production are not sustainable and issues of climate change and global warming call for new methods to produce energy from carbon- neutral and renewable sources [1]. At present, the main technologies for decontaminating municipal, industrial and agricultural wastewater depend on energy consuming aerobic bio-processes developed many years ago. About $70 \%$ of the energy utilized in wastewater treatment is spent in aeration plants [11]. It has been reported that the yearly cost of treating United State of America's wastewater is $\$ 42.2$ billion and many more billions will 
be required in future decades to maintain and replace ageing infrastructure.

To help offset the large power demand from aerobic treatment, it is important that efficient processes be developed that can convert the contaminant loads in domestic or industrial wastewater to useable forms of energy. Microbial fuel cell is an exciting potential technology for sustainable treatment of wastewater and electricity generation $[5,14]$. The technology makes use of electroactive microorganisms that have the genes for the release of extracellular electrons, found in wastewater as bio-catalysts to treat wastewater and concomitantly generate electricity. In MFC, biochemical reactions are carried out by microorganisms in an anaerobic anode chamber, generating electrons and protons through the breakdown of the organic substrates entrenched in wastewater [20]. Concurrently, electrochemical reactions occur in the aerobic cathode chamber, whereby electrons and protons are accepted through an oxygen reduction reaction [16]. The power output in MFC is usually affected by many factors such as chemical or biochemical processes, mechanical engineering of the reactor configuration and operational conditions. Amongst these factors, operational temperature and $\mathrm{pH}$ is one of the most influencing factor. Temperature and $\mathrm{pH}$ affect the microbial kinetics and the type of microorganism that reside in the anodic biofilm of the wastewater chamber [33]. For adequate development of the microbial community (growth and respiration of exoelectrogenic microorganisms) and structure, regulation of changes in temperature and $\mathrm{pH}$ is very crucial for optimal performance of MFC. The growing $\mathrm{pH}$ of the anodic chamber of MFC controls the microbial activity [34]. Currently, the gene coding for the release of these extracellular electrons by microorganisms has not been elucidated. Some species of bacteria such as Geobacter sulfurreducens, Rhodoferax ferrireducens, Geobacter metallireducens and Shewanella oneidensis have been reported to be efficient in MFCs [4].

This research examined the efficacy of using isolated exoelectrogenic bacteria or fungi and optimisation of MFC system parameters ( $\mathrm{pH}$ and temperature) to enhance the treatment of wastewater and increase power density which is the major challenge of microbial fuel cell. It molecularly characterised the exoelectrogenic isolates to pave way for further sequence analysis of the isolates' genome in order to understand the mechanism and the gene coding for electrogenic nature of the present and other known isolates.

\section{Materials and Methods}

\section{Sample collection}

Environmental samples (bottom wastewater samples) were collected from swamp, landfill leachate, kitchen, cassava milling site and abattoir using airtight plastic containers. The samples were obtained in Abakaliki Local Government Area of Ebonyi State, Nigeria within the respective geographical coordinates (latitudelongitude); $6.2597^{\circ} \mathrm{N} \quad 8.1086^{\circ} \mathrm{E}, \quad 6.3291^{\circ} \mathrm{N} \quad 8.1161^{\circ} \mathrm{E}$, $6.2971^{\circ} \mathrm{N} 8.1126^{\circ} \mathrm{E}, 6.3230^{\circ} \mathrm{N} 8.1122^{\circ} \mathrm{E}$, and $6.3230^{\circ} \mathrm{N}$ $8.1122^{\circ} \mathrm{E}$.

\section{Preliminary screening/isolation of exoelectrogenic bacteria and fungi}

The wastewater samples were used to screen for microorganisms that are capable of generating voltage through the release of extracellular electrons. Five double chamber MFCs were constructed in accordance with Padma and Dirk [18]. Two hundred and fifty milliliter $(250 \mathrm{ml})$ each of wastewaters collected from five different sources as mentioned above were poured into respective anode chamber of the MFC while $250 \mathrm{ml}$ each of $0.1 \mathrm{M}$ of Potassium manganate (vii) solution $\left(\mathrm{KMnO}_{4}\right.$ Sigma Aldrich, US) were poured into the cathode chamber. After three days of observation of generation of current/voltage using a millimeter (DT9205A), the anode electrodes were pulled out and the biofilm formed at each anode electrodes of the 5 different MFCs were washed out (diluted) with deionized water into five conical flasks. Axenic cultures of bacteria and fungi were isolated with the method described by Madigan [13] and stored in a refrigerator at $4{ }^{\circ} \mathrm{C}$ for further screening. A total of 20 axenic cultures were obtained. These were screened for wastewater cleaning and electricity generation capacity using MFC by inoculating the isolates into respective autoclaved synthetic kitchen wastewater. A control setup was also made in which none of the isolates was inoculated.

Designing of synthetic wastewater. Five thousand milliliter of kitchen wastewater sample (handy and contains 
substrate that may favour the growth of microorganisms) and $5000 \mathrm{ml}$ of $0.1 \mathrm{M} \mathrm{KMnO}_{4}$ were used for the 20 MFCs setup for the 20 isolates. Firstly, the kitchen wastewater was filtered using muslin cloth followed by the addition of $50 \mathrm{~g}$ of nutrient broth media to the filtrate. The solution was thoroughly mixed together and sterilized by autoclaving at $121^{\circ} \mathrm{C}$ for $15 \mathrm{~min}$. Secondly, $250 \mathrm{ml}$ each of the sterilized wastewater and $\mathrm{KMnO}_{4}$ was poured in each anode and cathode chamber of the 20 MFC setup respectively, to assess the wastewater treatment and electricity generation potentials of each isolate within three days.

Isolates that generated a higher voltage/current were selected and stored in refrigerator at $4^{\circ} \mathrm{C}$ for further assessment. Amongst the 20 isolates, 12 isolates generated voltages and were selected. The 12 isolates that generated significant voltages were further assessed for four days using the same method as applied above. All the screenings were carried out at ambient temperature and $\mathrm{pH}$ of the solutions. A total of 5 best isolates that generated higher voltages within the 4 days of assessment were selected for optimization in further assessment.

\section{Experimental design}

The experiment was carried out using $5 \times 4 \times 4$ factorial experimental units in a completely randomized design (CRD). Factor 1, 2 and 3 represent microbial isolates, $\mathrm{pH}$ levels and temperature levels, respectively. The data collected were analyzed using the Statistical Package for Social Sciences (SPSS) version 20.0. The variables were subjected to a three-way analysis of variance (ANOVA) test using $5 \times 4 \times 4$ factorial in a completely randomized design. The significant means were compared using Duncan Multiple Range Test at 5\% probability level.

\section{Optimization study of MFC system parameters}

The MFC setup was optimized by the addition of nutrient ( $5 \mathrm{ml}$ of glucose solution $(2 \% \mathrm{w} / \mathrm{v})$ ) at the anode chamber, $2 \mathrm{ml}$ of $1 \% \mathrm{w} / \mathrm{v}$ Manganese (iv) oxide $\left(\mathrm{MnO}_{2}\right.$ Wharfdale Lab) catalyst at the cathode chamber, variation in $\mathrm{pH}$ and temperature and increase in the surface area of the anode and cathode electrodes (graphite rods).

\section{Features of the microbial isolates}

The five best isolates that showed higher voltages were used to assess the features of these isolates by subjecting the MFC setup to different $\mathrm{pH}$ and temperature under the system parameters as above. The power density $\left(\mathrm{W} / \mathrm{m}^{2}\right)$ produced at various $\mathrm{pH}$ and temperature by each isolate indicates its capacity for wastewater treatment and electricity generation. The power density was determined as the product of the voltage (V) and current (I) per surface area (A) of the graphite rod electrode (Power density $\left.\left(\mathrm{W} / \mathrm{m}^{2}\right)=\mathrm{VI} / \mathrm{A}\right)$.

To determine the optimal $\mathrm{pH}$ of the isolates, the anodic chamber of each of the MFC setup was adjusted to the $\mathrm{pH}$ range of $6.0,7.5,8.5$, and 9.5 at ambient temperature. The $\mathrm{pH}$ was adjusted using Sodium hydrogen carbonate (Lab Tech Chemicals, UK) and Potassium citrate (Lab. Tech. Chemicals). Determination of optimal temperature was carried out by incubating the MFC setup at different temperatures of $30,35,40$, and $45^{\circ} \mathrm{C}$ at optimal $\mathrm{pH}$ obtained in the study of the effect of $\mathrm{pH}$.

\section{Characterisation of bacterial and fungal isolates}

The isolates were identified through molecular characterization [25]. Genomic DNA extraction from fungal and bacterial isolates was performed by using the ZR Fungal/Bacterial DNA MiniPrep ${ }^{\mathrm{TM}}$ Kit (Zymo Research, USA) following the manufacturer's instructions. The 16S rRNA gene was amplified from genomic DNA obtained from bacterial cultures by PCR using universal primer: forward: F1 (5'-AGAGTTTGATCCTGGCTCAG$\left.3^{\prime}\right)$ and reverse: R5 (5'-ACGGCTACCTTGTTACGACTT-3') according to Weisburg et al. [24]. The $18 \mathrm{~S}$ rRNA of the fungal sequences were also amplified using primers ITS1 (5'-CTTGTTCATTTAGAGGAAGTAA-3') and ITS4 (5'-TCCTCCGCTTATTGATATGC-3') using conditions described by White et al. [25].

The PCR amplicons of the fungal and bacterial DNA were analysed by electrophoresis in 1\% (w/v) agarose gel with EtBr (Ethidium Bromide). DNA ladders of $2 \mathrm{~kb}$ were loaded in $5 \mu \mathrm{l}$ volumes, while $7 \mu \mathrm{l}$ of the sample was loaded with $2 \mu \mathrm{l}$ of loading dye. The gel was allowed to run for $2 \mathrm{~h}$ at $60 \mathrm{~V}$. The Gel results were visualized with a ChemiDoc ${ }^{\mathrm{TM}}$ MP System (Bio-Rad Laboratories, USA) to confirm the expected size of the product. The remaining PCR products were purified using NucleoSpin Gel and PCR Clean-up kit (Macherey-Nagel, Germany).

The sequencing of the purified PCR products was car- 
ried out with PRISM ${ }^{\mathrm{TM}}$ Ready Reaction Dye Terminator Cycle Sequencing Kit using the dideoxy chain termination method and electrophoresed with a model ABI PRISM $^{\circledR}$ 3500XL DNA Sequencer (Applied Biosystems, USA) by following the manufacturer's instructions. Chromas Lite version 2.33 software (Technelysium, Pty Ltd.) was used for the analysis of chromatograms resulting from sequencing reaction for good quality sequence. The resulting chromatograms were edited using BioEdit Sequence Alignment Editor [6]. The resulting consensus 16S rDNA and 18S rDNA sequences obtained were Blast in National Centre for Biotechnology Information (www.ncbi.nlm.nih.gov) database with the Basic Local Alignment Search Tool (BLASTn) for homology to identify the probable organism in question [2].

Phylogenetic analyses based on the 16S rRNA and 18S rRNA genes were further used to characterize the organism to establish evolutionary relationships among them and other known exoelectrogenic species. Mafft version 7.0 was employed in the multiple alignments of nucleotide sequences according to Katoh and Frith [9] while phylogenetic tree [10] was constructed using character based method (Maximum Likelihood) for comparing the set of data against the set of models of evolution using MEGA 6 according to Tamura et al. [22]. Putative chimeric sequences were identified using the Chimera Buster 1.0 software. Manipulation and tree editing were carried out using TreeView software [19]. The phylogenetic comparison of the present isolates with known

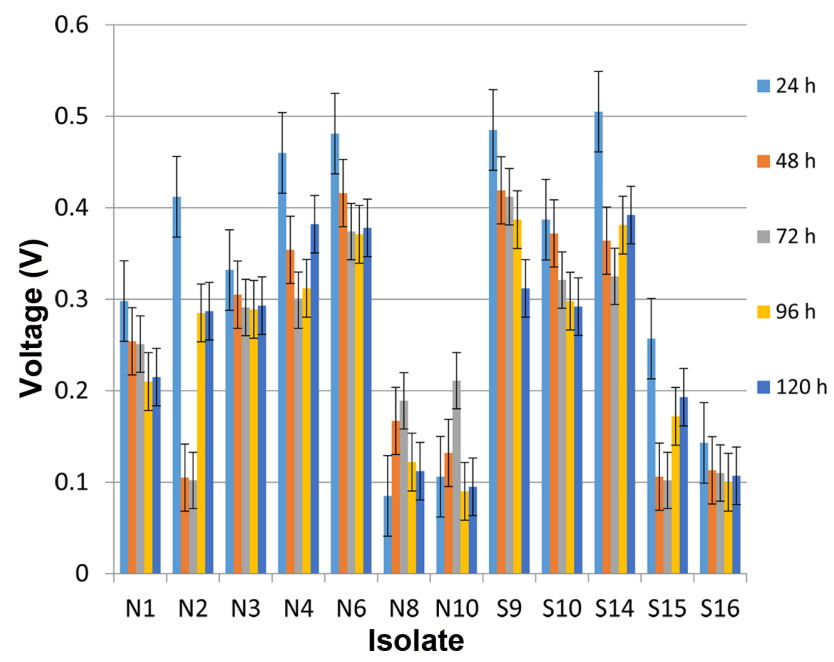

Fig. 1. Voltages generated by isolates in the MFC setup at different time intervals before optimization. exoelectrogenic isolates was carried out using their translated nucleotide sequences. Translation of nucleotide sequence to amino acid (peptide) sequence was carried out using GENSCAN bioinformatics tool [31].

\section{Results}

\section{Power density produced by Isolates}

Based on the preliminary screening for isolates that have potential of generating electricity (voltages) during wastewater treatment, a total of 12 isolates were obtained. These include 7 bacteria (N1, N2, N3, N4, N6, $\mathrm{N} 8$, and $\mathrm{N} 10$ ) and 5 fungi (S9, S10, S14, S15, and S16) as shown in Fig. 1. Five isolates (N4, N6, S9, S10, and S14) that generated higher voltages of $0.460,0.481,0.485$, 0.387 , and $0.505 \mathrm{~V}$, respectively were selected for optimization through the study of effect of variations in $\mathrm{pH}$ and temperature on the isolates for enhanced MFC performance. The power density $\left(\mathrm{W} / \mathrm{m}^{2}\right)$ produced by these isolates within time intervals at varied $\mathrm{pH}$ and tem-

Table 1. Power density $\left(\mathrm{W} / \mathrm{m}^{2}\right)$ of each isolate at four levels of $\mathrm{pH}$ within time intervals.

\begin{tabular}{ccccccc}
\hline \multirow{2}{*}{$\mathrm{pH}$} & \multirow{2}{*}{ Isolates } & \multicolumn{5}{c}{ Time (h) } \\
\cline { 3 - 7 } 6.0 & N4 & 0.00 & 0.00 & 0.00 & 0.00 & 0.00 \\
& N6 & 0.01 & 0.02 & 0.02 & 0.01 & 0.02 \\
& S9 & 0.00 & 0.02 & 0.00 & 0.00 & 0.00 \\
& S10 & 0.05 & 0.04 & 0.07 & 0.06 & 0.00 \\
& S14 & 0.04 & 0.02 & 0.02 & 0.05 & 0.02 \\
& N4 & 0.21 & 0.12 & 0.16 & 0.16 & 0.06 \\
& N6 & 0.14 & 0.10 & 0.11 & 0.14 & 0.15 \\
& S9 & 0.03 & 0.04 & 0.11 & 0.12 & 0.01 \\
& S10 & 0.18 & 0.03 & 0.02 & 0.02 & 0.02 \\
& S14 & 0.10 & 0.14 & 0.05 & 0.05 & 0.10 \\
& N4 & 0.32 & 0.33 & 0.29 & 0.37 & 0.40 \\
& N6 & 0.26 & 0.24 & 0.22 & 0.14 & 0.20 \\
& S9 & 0.21 & 0.23 & 0.23 & 0.21 & 0.12 \\
& S10 & 0.45 & 0.35 & 0.34 & 0.28 & 0.05 \\
& S14 & 0.24 & 0.22 & 0.16 & 0.16 & 0.10 \\
& N4 & 0.26 & 0.24 & 0.24 & 0.21 & 0.03 \\
& N6 & 0.63 & 0.52 & 0.62 & 0.29 & 0.25 \\
& S9 & 0.21 & 0.20 & 0.18 & 0.21 & 0.13 \\
& S10 & 0.15 & 0.13 & 0.13 & 0.15 & 0.13 \\
& S14 & 0.19 & 0.20 & 0.24 & 0.23 & 0.01 \\
\hline \multirow{6}{*}{ 9.5yyyyyy}
\end{tabular}


Table 2. Power density $\left(\mathrm{W} / \mathrm{m}^{2}\right)$ of each isolate at four levels of temperature within time intervals.

\begin{tabular}{ccccccc}
\hline \multirow{2}{*}{$\begin{array}{c}\text { Temp } \\
\left({ }^{\circ} \mathrm{C}\right)\end{array}$} & Isolates & \multicolumn{5}{c}{ Time $(\mathrm{h})$} \\
\cline { 3 - 7 } $30^{\circ} \mathrm{C}$ & $\mathrm{N} 4$ & 0.64 & 0.34 & 0.28 & 0.37 & 0.34 \\
& $\mathrm{~N} 6$ & 0.86 & 0.20 & 0.15 & 0.14 & 0.27 \\
& $\mathrm{~S} 9$ & 1.07 & 0.47 & 0.10 & 0.09 & 0.08 \\
& $\mathrm{~S} 10$ & 1.48 & 0.38 & 0.29 & 0.55 & 0.61 \\
& $\mathrm{~S} 14$ & 0.63 & 0.30 & 0.12 & 0.30 & 0.37 \\
$35{ }^{\circ} \mathrm{C}$ & $\mathrm{N} 4$ & 1.09 & 0.49 & 0.18 & 0.17 & 0.14 \\
& $\mathrm{~N} 6$ & 0.52 & 0.29 & 0.12 & 0.07 & 0.17 \\
& $\mathrm{~S} 9$ & 0.62 & 0.22 & 0.31 & 0.19 & 0.26 \\
& $\mathrm{~S} 10$ & 1.55 & 0.94 & 0.43 & 0.53 & 0.63 \\
& $\mathrm{~S} 14$ & 1.46 & 0.22 & 0.16 & 0.04 & 0.28 \\
$40{ }^{\circ} \mathrm{C}$ & $\mathrm{N} 4$ & 1.44 & 0.34 & 0.24 & 0.57 & 0.71 \\
& $\mathrm{~N} 6$ & 1.59 & 0.80 & 0.80 & 0.62 & 0.60 \\
& $\mathrm{~S} 9$ & 1.51 & 1.48 & 0.64 & 0.53 & 0.49 \\
& $\mathrm{~S} 10$ & 1.39 & 0.71 & 0.66 & 0.66 & 0.63 \\
& $\mathrm{~S} 14$ & 0.41 & 0.18 & 0.11 & 0.03 & 0.03 \\
$45{ }^{\circ} \mathrm{C}$ & $\mathrm{N} 4$ & 0.44 & 0.44 & 0.18 & 0.06 & 0.05 \\
& $\mathrm{~N} 6$ & 1.15 & 0.33 & 0.12 & 0.01 & 0.12 \\
& $\mathrm{~S} 9$ & 0.83 & 0.29 & 0.14 & 0.19 & 0.25 \\
& $\mathrm{~S} 10$ & 1.35 & 0.68 & 0.53 & 0.37 & 0.31 \\
& $\mathrm{~S} 14$ & 0.68 & 0.30 & 0.27 & 0.25 & 0.22 \\
\hline
\end{tabular}

perature are shown in Table 1 and 2.

In the variation of $\mathrm{pH}$, it was observed that the highest power density of $0.63 \mathrm{~W} / \mathrm{m}^{2}$ was produced by the bacterial isolate, $\mathrm{N} 6$ at $\mathrm{pH}$ of 9.5 within $24 \mathrm{~h}$. This was followed by isolates, $\mathrm{S} 10, \mathrm{~N} 4, \mathrm{~S} 14$, and $\mathrm{S} 9$ at $\mathrm{pH}$ of 8.5 as shown in Table 1 . In the variation of temperature which was carried out at a $\mathrm{pH}$ of 8.5, there was a significant increase in voltage as shown in Table 2 . The bacterial isolate, N6 produced the highest power density of $1.59 \mathrm{~W} / \mathrm{m}^{2}$ at $40^{\circ} \mathrm{C}$ within $24 \mathrm{~h}$ while the fungal isolates S10, S9, and S14 produced their highest power density of $1.55,1.51$, and $1.46 \mathrm{~W} / \mathrm{m}^{2}$, respectively within $24 \mathrm{~h}$ at $35^{\circ} \mathrm{C}$ for $\mathrm{S} 10, \mathrm{~S} 14$, and $40^{\circ} \mathrm{C}$ for $\mathrm{S} 9$. The bacterial isolate, $\mathrm{N} 4$ produced the power density of $1.44 \mathrm{~W} / \mathrm{m}^{2}$ which was lower than that produced by the fungi.

\section{Molecular identification of isolates}

Molecular characterisation of the isolates through electrophoresis of the amplified 16S rRNA (bacteria) and 18S rRNA (fungi) as shown in Fig. 2, sequencing,

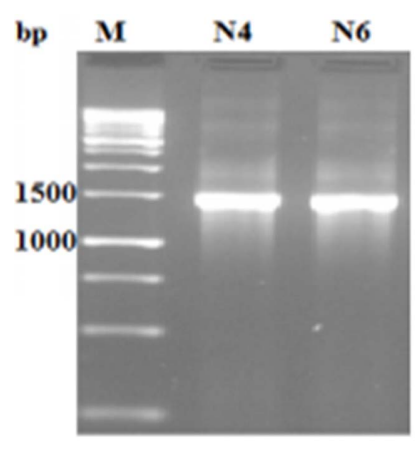

(Gel picture "A": Bacteria)

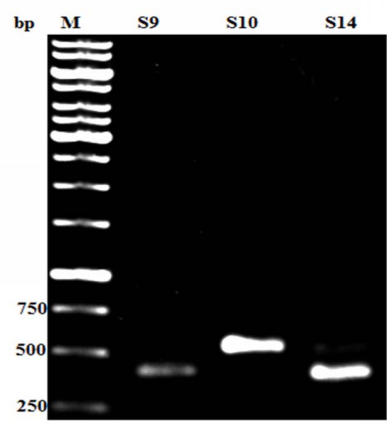

(Gel picture "B": Fungi)
Fig. 2. PCR profile of $16 S$ rRNA (Gel picture "A": Bacteria) and 185 rRNA (Gel picture "B": Fungi) fragment amplified from the bacterial and fungal isolates. " $M$ " represents the marker of $2 \mathrm{~kb} . \mathrm{N}$ and $\mathrm{S}$ represent the code of the isolates.

BLAST and construction of phylogenetic (Fig. 3) tree showed the true identity of the exoelectrogenic isolates compared to the database sequence (Table 3). Sequence alignment of the protein sequence and construction of phylogenetic tree of ten known exoelectrogenic microorganisms with the five present isolates showed the evolutionary relationship/closeness of the isolates as shown in Fig. 4.

\section{Discussions}

The major challenge of microbial fuel cells has been low voltage, current or power generation. This has been attributed to factors such as the exoelectrogenic microbial species, optimal environmental conditions for the growth of the microorganisms, nature and surface area of electrodes, cation exchange membrane and catholyte used in the cathode chamber. Most published reports on microbial community in MFC focused on the exploitation of electrogenic bacteria such as Rhodopseudomonas palustris and Shwanella oneidensis [8, 21, 23, 26]. This present research showed that fungal species are also electroactive for enhanced MFC performance.

In the preliminary screening, the 12 isolates generated significant voltages without optimization of the system parameters such as $\mathrm{pH}$, temperature, increase in surface area of anodic and cathodic electrodes and addition of glucose and catalyst. According to the report by Pratima et al. [28], increase in voltages or currents is also reflected in the power density produced in MFC setup. Increase in current densities results in increase in 


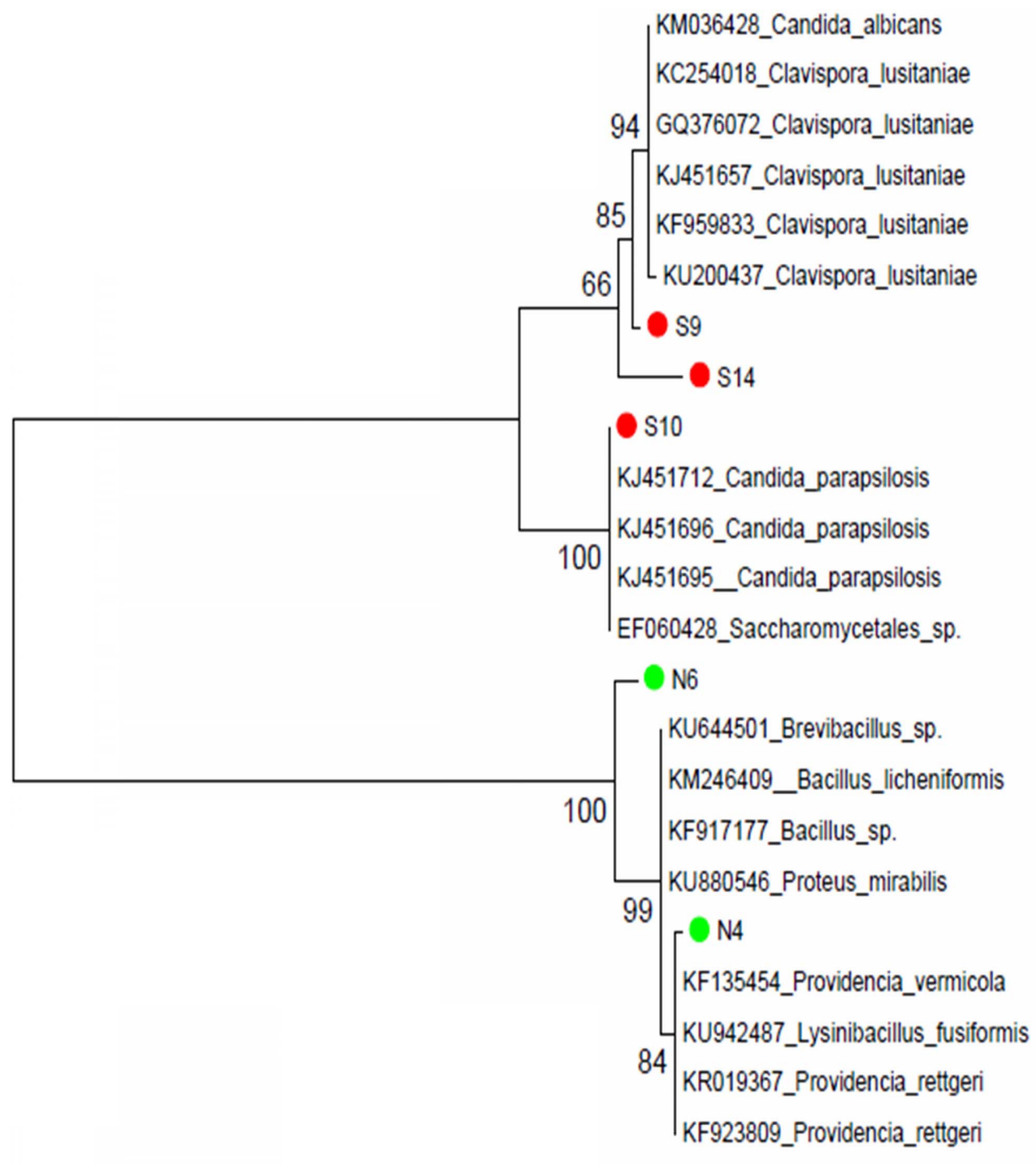

0.1

Fig. 3. Phylogenetic tree of the isolates using maximum likelihood method. Maximum Likelihood phylogenetic tree based on partial $16 \mathrm{~S}$ and $18 \mathrm{~S}$ rRNA gene sequence, showing the phylogenetic relationships between isolated bacteria and fungi and the most closely related strains from the GenBank. Numbers at the nodes indicate the levels of bootstrap support based on 1000 resampled data sets. Only values greater than $50 \%$ are shown.

Table 3. 16S rRNA and $18 \mathrm{~S}$ rRNA sequence identity of the bacterial and fungal isolates.

\begin{tabular}{cccc}
\hline $\begin{array}{c}\text { Isolate } \\
\text { code }\end{array}$ & $\begin{array}{c}\text { Sequence } \\
\text { length (bp) }\end{array}$ & $\begin{array}{c}\text { Closest related in } \\
\text { database }\end{array}$ & $\begin{array}{c}\text { Assigned Accession } \\
\text { number }\end{array}$ \\
\hline N4 & 761 & Providencia specie & KX548357.1 \\
N6 & 962 & Proteus specie & KX548358.1 \\
S9 & 422 & Clavispora lusitaniae & KX548359.1 \\
S10 & 541 & Candida parapsilosis & KX548360.1 \\
S14 & 697 & Clavisporalusitaniae & KX548361.1 \\
\hline
\end{tabular}

power density [29].

Optimization of the microbial fuel cell system parameters through the variation of $\mathrm{pH}$ and temperature, increase in surface area of electrode and addition of glucose showed a significant increase in power density produced by each of the 5 best exoelectrogenic isolates. When the $\mathrm{pH}$ of each MFC was adjusted to four different levels at ambient temperature, there was responsive variation in power density. The power density depreciated in all the isolates' MFC setup at the $\mathrm{pH}$ of 6.0 and 


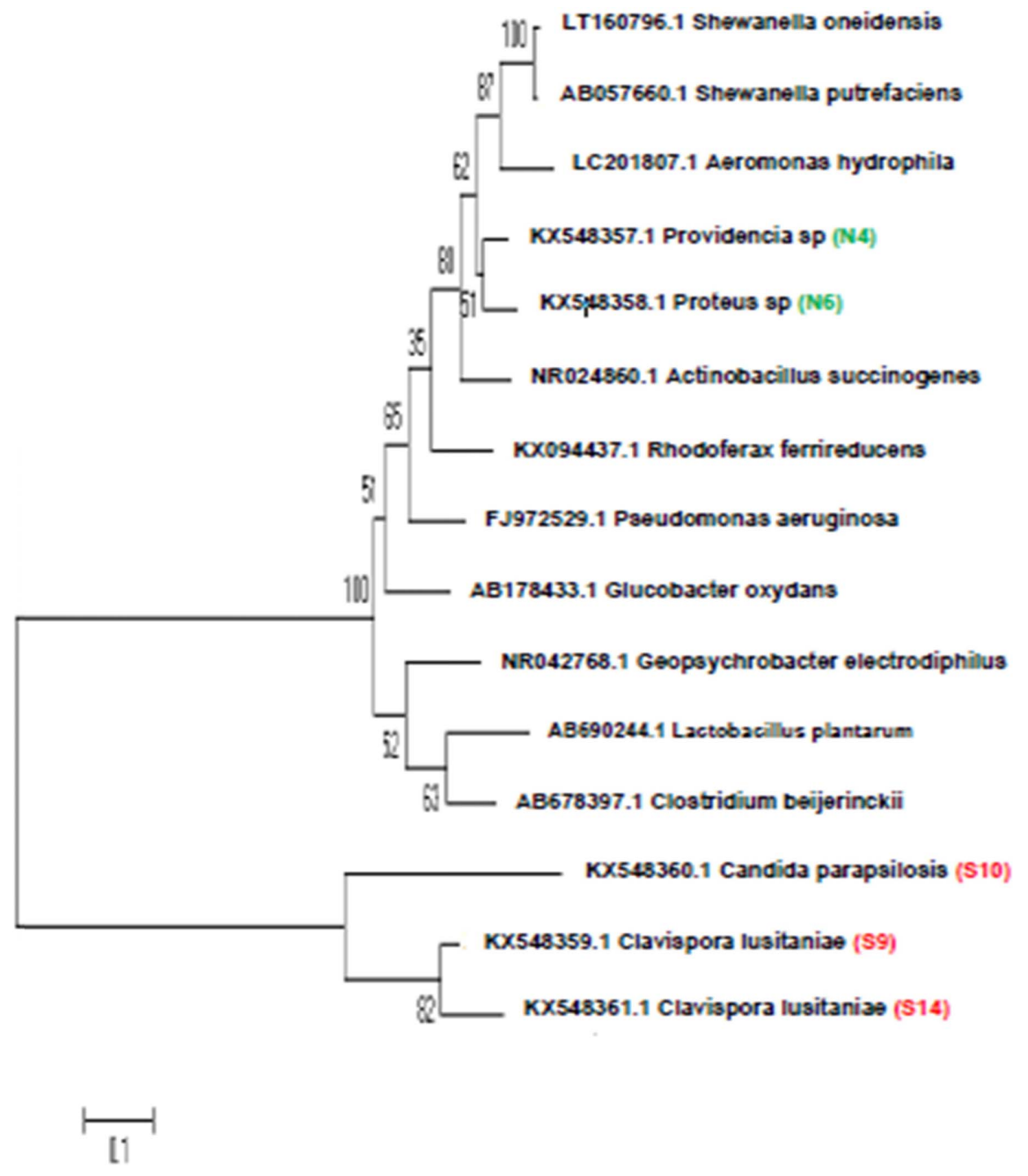

Fig. 4. Phylogenetic tree comparison of the five exoelectrogenic isolates with ten known exoelectrogenic strains in the GenBank database.

appreciated at the $\mathrm{pH}$ range of 8.5-9.5 within time intervals. This is consistent with the report by He et al. [7] that "the measurement of electricity generation from air cathode MFC with a mixed culture of bacteria showed that optimal $\mathrm{pH}$ was between 8 and 10 with higher current generation compared to lower or higher $\mathrm{pH}$ ". The result showed that exoelectrogenic bacterial and fungal species perform better at alkaline $\mathrm{pH}$. Amongst the isolates, Proteus species (N6) produced the highest power density of $0.63 \mathrm{~W} / \mathrm{m}^{2}$ the of 9.5 within $24 \mathrm{~h}$, followed by Clavispora lusitaniae (S10) and Providencia specie (N4) that generated power densities of $0.45 \mathrm{~W} / \mathrm{m}^{2}$ and $0.40 \mathrm{~W} /$ $\mathrm{m}^{2}$ the of 8.5 within $24 \mathrm{~h}$ and $120 \mathrm{~h}$, respectively. The variations in power density generated by these isolates at a particular $\mathrm{pH}$ showed that $\mathrm{pH}$ has significant effect in the performance of MFC. In the study of effect of $\mathrm{pH}$ on nutrient dynamics and electricity generation by MFC, Sebastia et al. [30] observed that power density was increased by $80 \%$ from $0.36 \mathrm{~W} / \mathrm{m}^{3}$ at $\mathrm{pH}$ of 6 to $0.66 \mathrm{~W} / \mathrm{m}^{3}$ at $\mathrm{pH}$ of 9.5 but dropped to $0.5 \mathrm{~W} / \mathrm{m}^{3}$ the of 10.

The study the of four levels of temperature at fixed $\mathrm{pH}$ of 8.5 showed a high boost in power output by the isolates. All the isolates produced their highest power densities at the temperature range of $35-40^{\circ} \mathrm{C}$. Proteus. sp. (N6) and Candida parapsilosis (S10) produced significantly higher power densities of 1.59 and $1.55 \mathrm{~W} / \mathrm{m}^{2}$ at temperatures of 40 and $35^{\circ} \mathrm{C}$ within $24 \mathrm{~h}$, respectively. These 
power densities were high compared to other reported power generated by bacteria during wastewater treatment in a microbial fuel cell. The fungal isolates, S9 and S14 produced higher power than the bacterial isolate, $\mathrm{N} 4$. This shows that under optimal $\mathrm{pH}$ and temperature conditions, fungi have the potential of producing more power than bacteria in a microbial fuel cell. According to Logan [32], the pathogenic yeast, $P$. anomala belonging to the fungi kingdom is capable of power generation in an MFC. Behera et al. [3] reported that maximum coulombic (7.39) and energy (13.14\%) efficiencies in MFC were obtained at $40^{\circ} \mathrm{C}$ but very low at $20^{\circ} \mathrm{C}$. The low voltage obtained at $30^{\circ} \mathrm{C}$ is an indication that exoelectrogenic microorganisms perform better in the temperature range of $35-45^{\circ} \mathrm{C}$. Though the optimum temperature for the microorganisms may vary depending on species it still remains relatively close. Li et al. [12] reported that in a microbial fuel cell experiment, coulombic efficiencies were $8.65,8.53$, and $13.24 \%$ at temperatures of 30,37 , and $43{ }^{\circ} \mathrm{C}$, respectively.

An increase in power density at certain temperatures and $\mathrm{pH}$ indicates that the isolates would perform better in MFC at such conditions. Optimization shows that the increase in surface area of electrodes, nutrients, $\mathrm{pH}$, and temperature have high influence on MFC performance. The observed increase and decrease in power densities within time interval could be attributed to microbial metabolism and agitation. This could be as a result of competition for the available nutrients or inhibition. Osman et al. [17] reported that MFC electrode fouling and the formation of metabolites by the microbial community affected the performance of MFC in a commercial application. The decrease in power output in some of the MFC setup at certain times beyond $24 \mathrm{~h}$ could be a result of the isolates utilizing their own product as a source of energy and lack of agitation of the setup for even substrate distribution within the chamber.

Although these present exoelectrogenic isolates are pathogenic, they have the potential for extracellular transfer of electrons to insoluble electron acceptors, such as the anodes of MFC. According to Zuo et al. [27], Ochobactrum anthropi, a pathogenic bacterium exhibited electrogenic property with Pseudomonas aeruginosa in different MFC setups. This suggests that electrogenesis may be a selective feature for opportunistic pathogens; a condition that needs further assessment [17].

It was observed in the phylogenetic analysis of the present isolates with already known exoelectrogenic isolates that these microorganisms have a similar amino acid sequence with two clusters for bacterial and fungal strains. The present exoelectrogenic bacterial isolates, Proteus (N6) and Providencia sp (N4) are closely related (62\% similar) to the mostly reported exoelectrogenic microorganisms, shewanella oneidensis [32] and shewanella putrefaciens. Further sequence analysis of these isolates based on their evolutionary trend could reveal more features that elucidate the gene responsible for the exoelectrogenic nature of these isolates.

Conclusively, the findings in this research have shown that a $\mathrm{pH}$ range of 8.5 to 9.5 and a temperature of $35-40^{\circ} \mathrm{C}$ favour the growth and respiration of the isolated exoelectrogenic bacteria and fungi. Thus, tropical environments harbour large species/strains of electrogenic microorganism that can alleviate the stress and cost of activated sludge method of wastewater treatment and boost electricity generation if well explored. This study has shown that some fungi possess great exoelectrogenic potential as well as perform better than bacteria in MFC. A good knowledge of the optimal temperature and $\mathrm{pH}$ and proper system architecture which has been established in this study would enhance MFC performance. It is, therefore, recommended that further research should be carried out to study the effect of increase in a time interval and up scaling using continuous or batch flow method to maximize utilization for commercial purposes. Also, to understand the gene or molecular mechanisms underlying the release of these extracellular electrons by the potential microorganisms. This would pave way for genetic engineering of other inert isolates and improve MFC as great machinery to tackle the growing environmental pollution and energy crises.

\section{Acknowledgments}

Nwagu, K.E is highly indebted to Dr. B.R Aremu of North West University, Mafikeng, South Africa for her great assistance in the molecular work of this research. We wish to express our profound gratitude to the lecturers in Department of Genetics and Biotechnology, University of Calabar, Nigeria for their unique encouragement and supervision of this research. 


\section{Conflict of Interest}

The authors have no financial conflicts of interest to declare.

\section{References}

1. Abhilasha SM, Sharma VN. 2009. Production from various wastewaters through microbial fuel cell technology. J. Biochem. Techol. 2: 133-137.

2. Altschul SF, Gish W, Miller W, Myers EW, Lipman DJ. 1990. Basic local alignment search tool. J. Mol. Biol. 215: 403-410.

3. Behera M, Murthy SS, Ghangrekar MM. 2011. Effect of operating temperature on performance of microbial fuel cell. Water Sci. Technol. 64: 917-922.

4. Du Z, Li H, Gu T. 2007. A state of the art review on microbial fuel cells: A promising technology for wastewater treatment and bioenergy. Biotechnol. Adv. 25: 464-482.

5. Franks AE, Nevin KP. 2010. Microbial fuel cells; a current review. Energies 3: 899-919.

6. Hall TA. 1999. BioEdit: a user friendly biological sequence alignment editor and analysis program for Windows 95/98/NT. Nucleic Acids Symp. Ser. 41: 95-98.

7. He Z, Huang Y, Manohar AK, Mansfeld F. 2008. Effect of electrolyte $\mathrm{pH}$ on the rate of the anodic and cathodic reactions in an aircathode microbial fuel cell. Bioelectrochemistry 74: 78-82.

8. Karmakar S, Kundu K, Kundu S. 2010. Design and Development of Microbial Fuel cells. pp. 1029-1034. In Current Research, Technology and Education Topic in Applied Microbiology and Microbial Biotechnology.

9. Katoh K, Frith MC. 2012. Adding unaligned sequences into an existing alignment using MAFFT and LAST. Bioinformatics 28 : 3144-3146.

10. Kudipudi S, Allam AR, Sridhar GR, Srinubabu G. 2008. Methodology for phylogenetic tree construction. J. Proteomics Bioinform. 1: 5-11.

11. Li B, Scheible K, Curtis M. 2011. Electricity generation from anaerobic wastewater treatment in microbial fuel cell. Water Environ. Res. 11095: 1-62.

12. Li LH, Sun YM, Yuan ZH, Kong XY, Li Y. 2013. Effect of temperature on power generation of microbial fuel cell. Environ. Technol. 34: 1929-1934.

13. Madigan MT. 2012. Brock Biology of Microorganisms. 13th ed. San Francisco: Benjamin Cummings.

14. Mahendra BG, Mahavarkar S. 2013. Treatment of wastewater and electricity generation using microbial fuel cell technology. Int. J. Res. Eng. Technol. 1: 277-282.

15. Muralidharan A, Ajay Babu OK, Nirmalraman K, Ramya M. 2011. Impact of salt concentration on electricity production in microbial hydrogen based salt bridge fuel Cells. Indian J. Fundam. Appl. L. Sci. 1: 178-184.

16. Mustakeem. 2015. Electrode materials for microbial fuel cells: nanomaterial approach. Mater. Renew. Sustain. Energy 4: 22.

17. Osman MH, Shah AA, Walsh FC. 2010. Recent progress and con- tinuing challenges in bio fuel cells. Part II: Microbial. Biosens. Bioelectron. 26: 953-963.

18. Padma S, Dirk BH. 2012. Microbial fuel cells: Future fuel technologies, National Petroleum Council (NPC) Study, Paper 13.

19. Page RDM. 1996. TreeView: An application to display phylogenetic trees on personal computer. Comput. Appl. Biosci. 12: 357358.

20. Pant D, Van Bogaert G, De Smet M, Diels L, Vanbroekhoven K. 2010. Use of novel permeable membrane and air cathodes in acetate microbial fuel cells. Electrochem. Acta 55: 7710-7716.

21. Park T, Ding W, Chend S, Brar MS, Ma AP, Tun HM, et al. 2014. Microbial community in microbial fuel cell (MFC) medium and effluent enriched with purple photosynthetic bacterium (Rhodopseudomonas sp). AMB Express 4: 22.

22. Tamura K, Stecher G, Peterson D, Filipski A, Kumar S. 2013. MEGA6: Molecular Evolutionary Genetics Analysis version 6.0. Mol. Biol. Evol. 30: 2725-2729.

23. Watson VJ, Logan BE. 2010. Power production in MFCs inoculated with Shewanella oneidensis MR-1 or mixed cultures. Biotechnol. Bioeng. 105: 489-498.

24. Weisburg WG, Barns SM, Pelletier DA, Lane DJ. 1991.16S ribosomal DNA amplification for phylogenetic study. J. Bacteriol. 173: 697-703.

25. White TJ, Bruns T, Lee S, Taylor S. 1990. Amplification and direct sequencing of fungal ribosomal RNA genes for phylogenetics, pp. 315-322, In Inni MA, Gelfand DH, Sninsky JJ, White TJ (eds.), PCR Protocols: a guide to methods and applications. New York, NY: Academic Press.

26. Xing D, Zuo Y, Cheng S, Regan JM, Logan BE. 2008. Electricity generation by Rhodopseudomonas palustris DX-1. Environ. Sci. Technol. 42: 4146-4151.

27. Zuo Y, Maness PC, Logan BE. 2008. Electricity production from steam exploded corn stover biomass. Energy Fuels. 20: 17161721.

28. Pratima G, Piyush P, Komal J, Anjali M, Jasjeet KB, Lalit NM. 2012. Comparative study of microbial fuel cell for electricity generation by enriched exoelectron generating bacteria from environmental samples. Asian J. Biotechnol. 42: 137-142.

29. Zhang Y, Mo G, Li X, Zhang W, Zhang J, Ye J. et al. 2011. A graphene modified anode to improve the performance of microbial fuel cells. J. Power Sources 196: 5402-5407.

30. Sebastià P, Marc S, Marta C, Marina C, Dolors MB, Jesús C. 2010. Effect of $\mathrm{pH}$ on nutrient dynamics and electricity production using microbialfuel cells. Biores. Technol. 101 : 9594-9599.

31. Burge C, Karlin S. 1997. Prediction of complete gene structure in human genomic DNA. J. Mol. Biol. 268: 78-94.

32. Logan BE. 2009. Exoelectrogenic bacteria that power microbial fuel cells. Nat. Rev. Microbiol. 7: 375-381.

33. Cheng S, Xing D, Logan BE. 2011. Electricity generation of singlechamber microbial fuel cells at lowtemperatures. Biosens. Bioelectron. 26: 1913-1917.

34. Zhang ER, Liu L, Cui YY. 2013. Effect of PH on the performance of the anode in microbial fuel cells. Adv. Mat. Res. 608: 884-888. 